This manuscript was accepted and published by Energy \& Fuels, a journal of the American Chemical Society. 10.1021/ef201497k (http://dx.doi.org/10.1021/ef201497k).

This manuscript was placed into the present public repository with the consent of the Editor of Energy \& Fuels. Publication data of the final, corrected work:

Várhegyi, G.; Sebestyén, Z.; Czégény, Z.; Lezsovits, F.; Könczöl, S.: Combustion kinetics of biomass materials in the kinetic regime. Energy Fuels, 2012, 26, 1323-1335. doi: $\underline{10.1021 / \mathrm{ef} 201497 \mathrm{k}}$

\title{
Combustion Kinetics of Biomass Materials in the Kinetic Regime
}

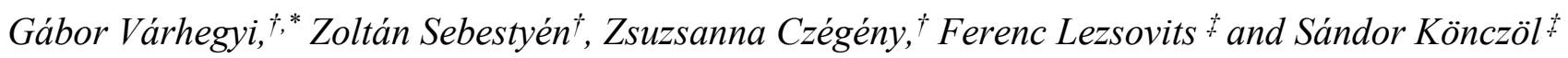

${ }^{\dagger}$ Institute of Materials and Environmental Chemistry, Chemical Research Center, Hungarian Academy of Sciences, P.O. Box 17, Budapest, 1525 Hungary; and *Department of Energy Engineering, Budapest University of Technology and Economics, Budapest, 1521 Hungary.

${ }^{*}$ To whom correspondence should be addressed.

E-mail: varhegyi.gabor@ttk.mta.hu, Tel. +36 1 4381148, Fax: +36 14381147

\begin{abstract}
Wheat straw, willow from an energy plantation and municipal sewage sludge were studied by thermogravimetry at linear and nonlinear heating programs in gas flows containing 4 and $20 \%$ oxygen. A kinetic scheme of successive devolatilization and char burn-off reactions was assumed. A distributed activation energy model (DAEM) was assumed for the devolatilization with a Gaussian distribution and a constant pre-exponential factor. The burn-off of the forming char was approximated by first order kinetics with respect to the amount of char. The dependence of the reactions on the oxygen concentration was described by power functions. This model gave suitable description for the wheat straw and sewage sludge. An additional partial reaction with accelerating kinetics was needed for describing the oxidative cellulose pyrolysis in the willow sample. The evaluations were carried out by the method of least squares. Series of 10 experiments were used for the determination of $9-17$ model
\end{abstract}


parameters. Good fit quality and reasonable kinetic parameters were obtained. Test evaluations revealed that the first order kinetics with respect to the amount of char is an adequate model; the assumptions of more complex char burn-off submodels did not led to notable improvements. The replacement of the DAEM devolatilization by simpler n-order kinetics gave inadequate performance. Earlier works with simpler models and linear temperature programs showed that the successive mechanism can be well approximated by parallel reactions. Such approximations proved to be viable in the present case, too.

Keywords: Wheat straw, willow; wood; sewage sludge; thermogravimetry; distributed activation energy model; combustion; char burn-off; pyrolysis; kinetic regime.

\section{Introduction}

Thermogravimetric experiments have a high precision while the temperature and the other experimental conditions of the sample are usually well known and well controlled. This makes it a useful tool for studying devolatilization and combustion in the kinetic regime. ${ }^{1,2}$ On the other hand, TGA can be employed only at relatively low heating rates because the true temperature of the sample may be unknown at high heating rates. This is particularly true in the presence of oxygen when high heating rates and/or larger sample masses can lead to ignition and uncontrolled combustion of the sample.

TGA measures the overall mass loss caused by the devolatilization and the burn-off of the formed char. These processes more or less overlap each other; accordingly their evaluation needs a suitable kinetic model that considers the simultaneous occurrence of both processes. ${ }^{3}$ This type of modeling is the main subject of the present work.

Biomass fuels and residues contain a wide variety of pyrolyzing species. Even the same chemical species may have differing reactivity if their pyrolysis is influenced by other species in their vicinity. The assumption of a distribution in the reactivity of the decomposing species frequently helps in the kinetic evaluation of the pyrolysis of complex organic samples. ${ }^{4}$ The distributed activation energy 
models (DAEM) have been used for biomass pyrolysis kinetics since 1985, when Avni et al. applied a DAEM for the formation of volatiles from lignin. ${ }^{5}$ Saidi et al. employed a DAEM in an actual combustion model. ${ }^{6}$ The use of DAEM in pyrolysis research was subsequently extended to a wider range of biomasses and materials derived from plants. Due to the complexity of the investigated materials the model was expanded to simultaneous parallel reactions (pseudocomponents) that were described by separate DAEMs. ${ }^{7-13}$ The increased number of unknown model parameters required least squares evaluation on larger series of experiments with linear and non-linear temperature programs. ${ }^{7,12,13}$ The model parameters obtained in this way allowed reliable prediction outside of the domain of the experimental conditions of the given kinetic evaluations. ${ }^{7,12,13}$

Numerous papers deal with the gasification and burn-off kinetics of lignocellulosic chars. This part of the literature has recently been extensively reviewed by Di Blasi. ${ }^{2}$

A combustion model usually needs the coupling of the devolatilization and the char burn-off reactions. ${ }^{14}$ Várhegyi et al. described slow tobacco burning by two successive reactions: a DAEM devolatilization and a subsequent char burn-off. ${ }^{15}$ The present work aims at testing the applicability of this model on a widely available agricultural residue (wheat straw), on an energy farm product (willow) and on a municipal sewage sludge. Besides, three additional topics will be investigated: the behavior of the cellulose component in the wood sample of the study; the relations between the DAEM approach and a simpler model with n-order devolatilization; and the approximation of the sequential mechanism by a parallel model.

\section{Samples and Methods}

2.1. Samples. A willow sample from an energy farm, a wheat straw as an agricultural by-product and a municipal sewage sludge from town Gyöngyös were investigated. Their analytical data are shown in Tables 1 and 2. The analyses were carried out by the ISD Dunaferr Co. The testing laboratory of this ironworks was accredited for biomass fuel analysis by the Office of DAP German Accreditation System for Testing. The heating value data were measured by an IKA 2000 calorimeter. The nitrogen and 
chlorine content were analyzed by semi-micro Kjeldahl method (ISO 333:1996-03), and by Eschka mixture method (ISO 587: 1997-05), respectively. The oxygen content was calculated by difference.

The samples were dried at room temperature. The wood and the straw were ground by a cutting mill to $<1 \mathrm{~mm}$ and further ground to $<0.12 \mathrm{~mm}$ particle size for the TGA experiments. The solid sewage sludge sample was pounded in an agate mortar to about $<0.1 \mathrm{~mm}$ particle size.

Table 1. Proximate analysis and heating values of the samples

\begin{tabular}{lcccccc}
\hline Sample & Moisture & $\begin{array}{c}\text { Ash } \\
\text { content } \\
\mathrm{m} / \mathrm{m} \%\end{array}$ & Volatiles & Char & $\begin{array}{c}\text { High } \% \mathrm{db} \\
\text { heating } \\
\text { value } \\
\mathrm{MJ} \mathrm{kg}^{-1}\end{array}$ & $\begin{array}{c}\text { Low } \\
\text { heating } \\
\text { value } \\
\mathrm{MJ} \mathrm{kg}^{-1}\end{array}$ \\
\hline Wheat straw & 12.8 & 4.1 & 79.4 & 20.6 & 16.45 & 14.94 \\
Willow & 14.4 & 1.2 & 83.2 & 16.8 & 16.82 & 15.25 \\
Sewage sludge & 15.4 & 38.8 & 50.6 & 49.4 & 9.84 & 8.76 \\
\hline
\end{tabular}

Table 2. Ultimate analysis of the samples ( $\mathrm{m} / \mathrm{m} \%$, dry basis)

\begin{tabular}{lcccccc}
\hline Sample & $\mathrm{C}$ & $\mathrm{H}$ & $\mathrm{O}$ & $\mathrm{N}$ & $\mathrm{S}$ & $\mathrm{Cl}$ \\
\hline Wheat straw & 40.9 & 5.3 & 35.8 & 0.7 & 0.10 & 0.33 \\
Willow & 42.1 & 5.4 & 36.4 & 0.4 & 0.09 & 0.01 \\
Sewage sludge & 22.0 & 3.2 & 16.7 & 2.9 & 0.89 & 0.09 \\
\hline
\end{tabular}

2.2. Thermogravimetric experiments. The TGA measurements were performed by a computerized Perkin-Elmer TGS-2 thermobalance. The samples were spread on a platinum sample holder of $\varnothing 6 \mathrm{~mm}$. The experiments were carried out in gas flows of $140 \mathrm{ml} / \mathrm{min}$. Nitrogen - oxygen mixtures with 4 and $20 \%$ (v/v, $\pm 5 \%$ rel.) oxygen were used. Prior to the experiments, the apparatus was purged with the carrier gas for $45 \mathrm{~min}$. Linear and stepwise heating programs were employed to increase the amount of information in the series of experiments. ${ }^{16}$ The $\mathrm{T}(\mathrm{t})$ programs of the present work are shown in Figure 1. The heating rate of the linear temperature programs were $4{ }^{\circ} \mathrm{C} / \mathrm{min}$ (black dots), $20^{\circ} \mathrm{C} / \mathrm{min}$ (red 
triangles) and $40^{\circ} \mathrm{C} / \mathrm{min}$ (blue squares). Two stepwise programs were employed for each sample (green solid line and magenta dashed line) that were composed of $20^{\circ} \mathrm{C} / \mathrm{min}$ heating ramps and isothermal sections of 30 minutes. The low temperature isothermals, up to $340^{\circ} \mathrm{C}$ serve for studying the devolatilization. The sections between 370 and $450^{\circ} \mathrm{C}$ give information on the kinetics of the char burnoff. The temperatures of the isothermal section differed for the three samples, as indicated in Figure 1, due to differences between the reactivity of the samples.
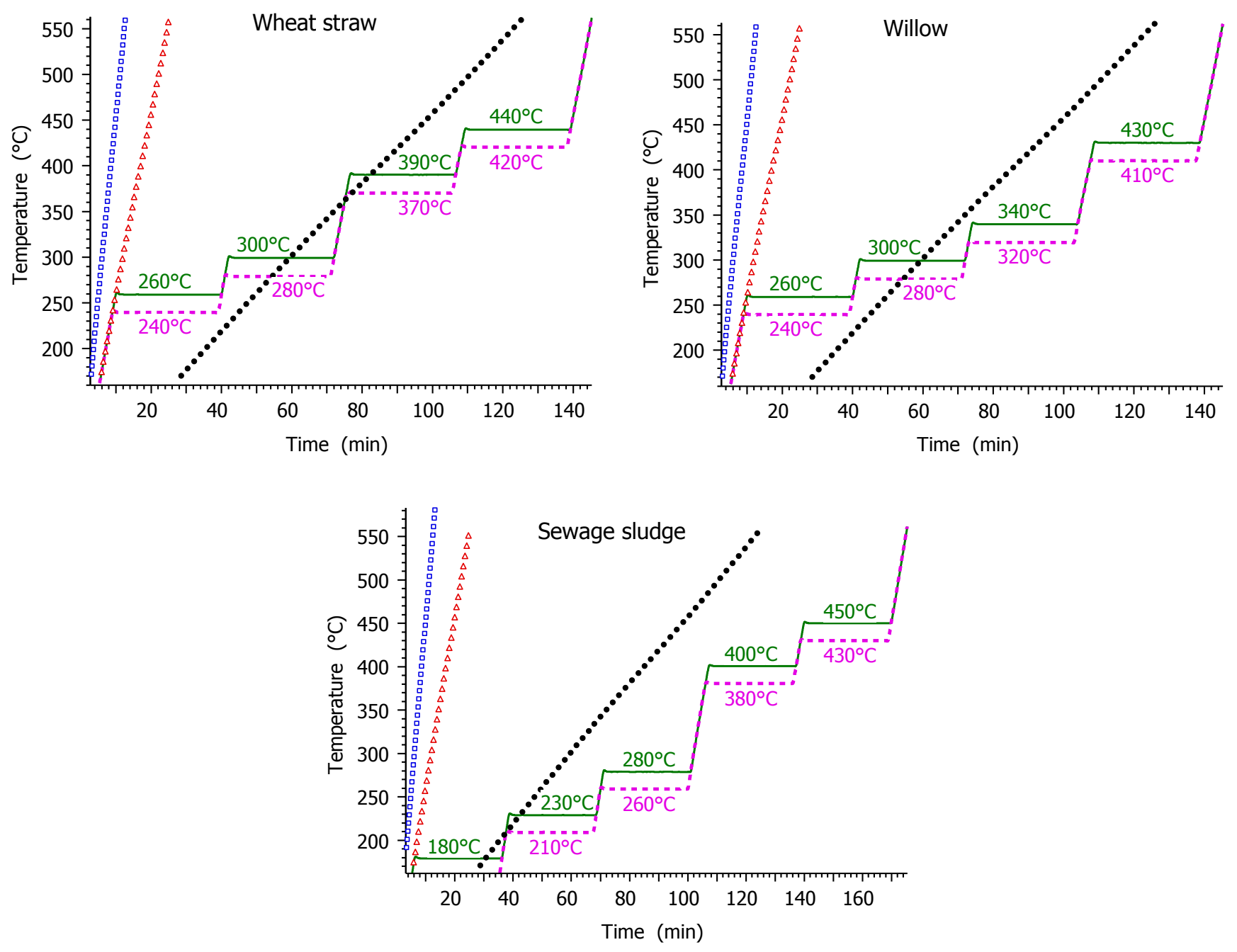

Figure 1. Temperature programs employed in the experiments. (See the explanations in the text.)

Each TGA experiment was normalized by the initial dry sample mass. For this purpose the sample mass measured at $160^{\circ} \mathrm{C}$ was selected (a temperature after the drying section and before a significant level of devolatilization). The sample mass normalized in this way is denoted by $m(t)$. Test 
experiments were carried out to select sample masses at which no ignition or significant self-heating occurred. Self heating can be a serious problem in combustion studies, as illustrated in earlier works. $^{16,17}$ Lower sample masses results obviously in smaller self-heating problems. Figure 2 shows test experiments on the willow sample which proved to be the most problematic from this respect. (This sample produced the highest reaction rates and its combustion heat was also the highest, as shown in Table 1.) The good agreement between the curves belonging to the different sample masses indicates the negligible influence of the transport processes on the results under the experimental conditions of the work. Figure 2 illustrates the repeatability of the results, too. An earlier work by the same instrument also shows a figure on the repeatability of the DTG curves at low sample masses. ${ }^{18}$ Table 3 displays the employed initial sample masses. The kinetic evaluation was carried out on the normalized mass loss rate, $-\mathrm{dm} / \mathrm{dt}$. The width of the evaluated temperature domains were $400^{\circ} \mathrm{C}$.
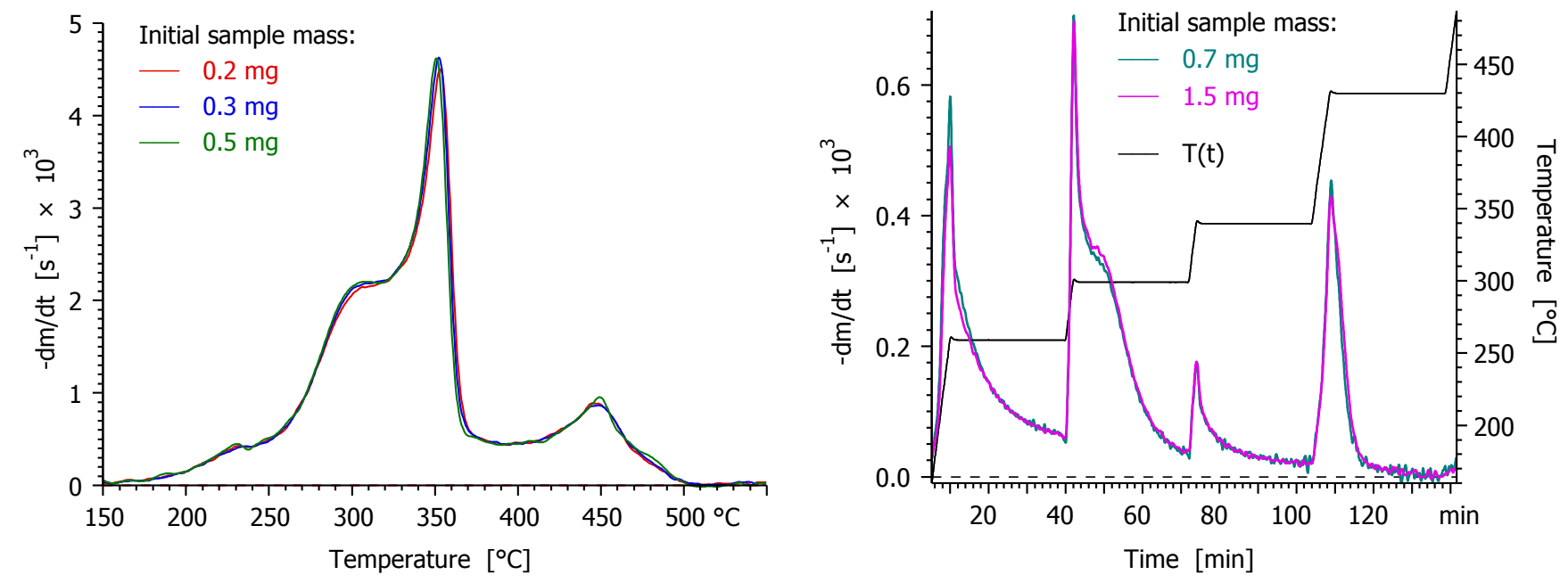

Figure 2. Tests on the effect of sample mass on the willow experiments. Normalized mass loss rates $(-\mathrm{dm} / \mathrm{dt})$ are compared at $20^{\circ} \mathrm{C} / \mathrm{min}$ heating rate (left) and at a stepwise $\mathrm{T}(\mathrm{t})$ program (right). 
Table 3. Initial sample masses used in the study (approximate values, mg)

\begin{tabular}{lcccc}
\hline Sample & $4^{\circ} \mathrm{C} / \mathrm{min}$ & $20^{\circ} \mathrm{C} / \mathrm{min}$ & $40^{\circ} \mathrm{C} / \mathrm{min}$ & stepwise $\mathrm{T}(\mathrm{t})$ \\
\hline Wheat straw & 1.5 & 0.5 & 0.3 & 1.5 \\
Willow & 1.5 & 0.5 & 0.3 & 1.5 \\
Sewage sludge & 5 & 1.6 & 0.8 & 3 \\
\hline
\end{tabular}

2.3. Numerical methods. Fortran 95 and $\mathrm{C}++$ programs were employed for the numerical calculations and for graphics handling, respectively. The employed numerical methods have been described in details earlier. ${ }^{15}$ The kinetic evaluation was based on the least squares evaluation of the $-\mathrm{dm} / \mathrm{dt}$ curves. The method ${ }^{19}$ used for the determination of $-\mathrm{dm} / \mathrm{dt}$ does not introduce considerable systematic errors into the least squares kinetic evaluation of experimental results. ${ }^{20}$ The differential equations of the model were solved numerically along the empirical temperature - time functions resulting in simulated data in the $t_{\mathrm{i}}$ points of the observations. The integration by $E$ in the DAEM kinetics of devolatilization was carried out by a Gauss - Hermite quadrature formula, as described by Donskoi and McElwain ${ }^{21}$ and Várhegyi et al. ${ }^{7}$ The domain of integration was rescaled by a factor of 0.2 to increase the precision of the integration. ${ }^{21}$ The first order kinetic equations of the DAEM were solved numerically using 180 quadrature points. Obviously the solution of the kinetic equations is not needed at those E values which result either in negligible reaction rates in the domain of evaluation or in a complete decomposition at low temperatures, below the temperature domain of the evaluation. The differential equation of the char burn-off kinetics was solved by an adaptive stepwise Runge-Kutta method ${ }^{22}$ The calculations were carried out on a desktop personal computer. The solution of the models discussed in the paper required around $30 \mathrm{~ms}$ time for an experiment with a non-linear $\mathrm{T}(\mathrm{t})$ function. The model parameters were determined by nonlinear least squares minimization which was carried out by a variant of the HookJeeves method. The Hook-Jeeves method is a slow but simple and dependable direct search algorithm. ${ }^{23}$ In our work the original algorithm was supplemented by parabolic interpolation for finding 
the optimal stepsizes. The starting values for the non-linear optimization were taken either from earlier work or from the results of the simpler models of the present work. The overall computer time of the evaluation of a series of experiments varied between a few minutes and a few hours.

\section{Results and discussion}

3.1. Evaluation by the method of least squares. The unknown model parameters were evaluated from series of 10 experiments by minimizing sum $S_{10}$ :

$$
S_{10}=\sum_{k=1}^{10} \sum_{i=1}^{N_{k}} \frac{\left[\left(\frac{d m}{d t}\right)_{k}^{o b s}\left(t_{i}\right)-\left(\frac{d m}{d t}\right)_{k}^{c a l c}\left(t_{i}\right)\right]^{2}}{N_{k} h_{k}^{2}}
$$

Here subscript $k$ indicates the experiments of the series evaluated. $t_{i}$ denotes the time values in which the discrete experimental values were taken, and $N_{k}$ is the number of the $t_{i}$ points in a given experiment. $h_{k}$ denotes the heights of the evaluated curves that strongly depend on the experimental conditions. The division by $h_{k}^{2}$ serves for normalization. The fit quality of the wholes series was characterized by the following quantity:

$$
\text { fit }_{10}(\%)=100 S_{10}^{0.5}
$$

When the fit quality of one experiment is characterized,

$$
\text { fit }_{1}(\%)=100 S_{1}^{0.5}
$$

is calculated, where $S_{1}^{0.5}$ equals to the root mean square difference between the calculated and observed data normalized by the peak height $(h)$ of the given experiment.

3.2. Coupling a DAEM devolatilization and a successive char burn-off reaction. The following successive reactions will be considered:

$$
\begin{aligned}
& \text { Biomass }+\mathrm{O}_{2} \rightarrow \text { char }+ \text { volatiles } \\
& \text { Char }+\mathrm{O}_{2} \rightarrow \text { ash }+\mathrm{CO}_{2}, \mathrm{CO}, \mathrm{H}_{2} \mathrm{O} \text { and minor gaseous/volatile products }
\end{aligned}
$$


Here the first reaction is the devolatilization influenced by the presence of oxygen. Let us normalize all masses by the initial sample mass. The normalized amounts of the unreacted part of the sample, char and ash will be denoted by $m_{\mathrm{ur}}$ and $m_{\mathrm{char}}$, and $m_{\mathrm{ash}}$, respectively.

As the reactions proceed, $m_{\mathrm{ur}}$ decreases from 1 to 0 . (Here $m_{\mathrm{ur}}=0$ means that no unreacted biomass remains at the end.) $m_{\text {char }}$ is zero at the beginning of an experiment. It reaches a maximum as the char forms and converges to zero again as the char burns off. The yields of the solid products in reactions 3 and 4 will be denoted by $y_{\text {char }}$ and $y_{\text {ash }}$, respectively. As the char burn-off proceeds, $m_{\text {ash }}$ converges from 0 to $y_{\text {char }} y_{\text {ash }}$.

$m^{\text {calc }}$ is the sum of the normalized masses of the solid components:

$$
\begin{aligned}
& m^{\text {calc }}(t)=m_{\text {ur }}(t)+m_{\text {char }}(t)+m_{\text {ash }}(t) \\
& \mathrm{d} m^{\text {calc }} / \mathrm{dt}=\mathrm{d} m_{\mathrm{ur}} / \mathrm{d} t+\mathrm{d} m_{\text {char }} / \mathrm{d} t+\mathrm{d} m_{\text {ash }} / \mathrm{d} t
\end{aligned}
$$

Note that $m^{\text {calc }}(0)=1$ and $m^{\text {calc }} \rightarrow y_{\text {char }} y_{\text {ash }}$ as $t \rightarrow \infty$.

The devolatilization is described by a DAEM. First order reactions are assumed for the parts of the sample that decompose at the various $E$ values. The effect of the oxygen concentration on the reaction rate is expressed by a factor of $C_{O_{2}}^{v_{\text {devol }}}$, where $C_{O_{2}}$ is the dimensionless $\mathrm{V} / \mathrm{V}$ concentration of the oxygen, and $v_{\text {devol }}$ is a reaction order parameter. Note that a dimensionless $C_{O_{2}}$ is necessary to provide a constant dimension for the preexponential factor, $A_{\text {devol }}$. (Otherwise the dimension of $A_{\text {devol }}$ would depend on parameter $v_{\text {devol. }}$ ) $C_{O_{2}}$ has values of 0.04 and 0.2 in the present work. Hence there is an ordinary differential equation for every possible $E$ value:

$$
-\mathrm{d} m_{\mathrm{ur}}(t, E) / \mathrm{dt}=C_{O_{2}}^{v_{\text {devol }}} A_{\mathrm{devol}} \mathrm{e}^{-E / R T} m_{\mathrm{ur}}(t, E)
$$

The amount of the unreacted sample in a given $t$ is composed from $m_{\mathrm{ur}}(\mathrm{t}, \mathrm{E})$ as:

$$
m_{\mathrm{ur}}(t)=\int_{0}^{\infty} D(E) m_{\mathrm{ur}}(t, E) \mathrm{d} E
$$

where $D(E)$ is a distribution function. $D(E)$ will be approximated by a Gaussian distribution:

$$
D(E)=(2 \pi)^{-1 / 2} \sigma^{-1} \exp \left[-\left(E-E_{0}\right)^{2} / 2 \sigma^{2}\right]
$$


$m_{\mathrm{ur}}(t)$ is calculated by solving eq. 6 numerically at 180 discrete $E$ values, as outlined in Section 2.3.

The char is formed from the mass loss of the unreacted fraction with yield $y_{\text {char }}$ and consumed by the burn-off. In this section the char burn-off is approximated by a simple kinetic relationship which is first order with respect to the amount of char and $v_{\text {char }}$ order with respect to the oxygen concentration:

$$
\mathrm{d} m_{\text {char }} / \mathrm{d} t=-\mathrm{d} m_{\text {ur }} / \mathrm{d} t y_{\text {char }}-A_{\text {char }} \exp \left(-E_{\text {char }} / \mathrm{RT}\right) m_{\text {char }} C_{O_{2}}^{v_{\text {char }}}
$$

Note that $-\mathrm{d} m_{\mathrm{ur}} / \mathrm{d} t \geq 0$ in the first term because the amount of the unreacted part of the biomass is monotonically decreasing. The ash is formed from the char burn-off with yield $y_{\text {ash }}$ and does not react any further in this model:

$$
\mathrm{d} m_{\text {ash }} / \mathrm{dt}=A_{\text {char }} \exp \left(-E_{\text {char }} / \mathrm{RT}\right) m_{\text {char }} C_{O_{2}}^{v_{\text {char }}} y_{\text {ash }}
$$

The model outlined above does not differentiate between the bulk and the surfaces of the particles. Later, in Section 3.6 such model variants will be employed for the char burn-off which are capable to describe formally such effects. A similar study for the devolatilization reactions, however, would be extremely difficult due to the complexity of the biomass materials. Hence we can only observe how well the devolatilization models of the study can describe the given experiments.

The solution of equations 5 - 10 was carried out numerically, as described in Section 2.3. High relative precision was used (better then $10^{-6}$ ) because it ensured the safety of the iterations and did not cause any difficulty. Nine unknown parameters were determined from ten experiments: $E_{0}, \sigma, A_{\text {devol}}$, $v_{\text {devol}}, y_{\text {char }}, E_{\text {char, }}, A_{\text {char, }}, v_{\text {char }}, y_{\text {ash }}$.

Figure 3 illustrates the results of the above models. Though the evaluation was based on series of ten experiments, only two experiments are presented in the figures of this article for a model variant at a given sample. See the Supporting Information for figures that show all evaluated experiments. The fit quality of the individual experiments, fit $t_{1}$ is indicated in each plot. The details of the fit can be observed by comparing the simulated mass loss rate curves (-) to their experimental counterparts (o). The partial curves are also displayed. Note that mass-loss rates are plotted. Hence the ash formation (green $x \times x$ ) is represented by negative mass-loss rates, while char curve (blue $-\cdot)$ ) starts with negative mass-loss 
rates (when the char formation is dominating) and continues with positive mass-loss rates (when the char burn-off is dominating). The consumption of the unreacted part of the sample (red - ) is obviously positive in this representation. The model parameters and the fit $t_{10}$ values are listed later, in Section 3.7, when the results of the various approaches are compared. 

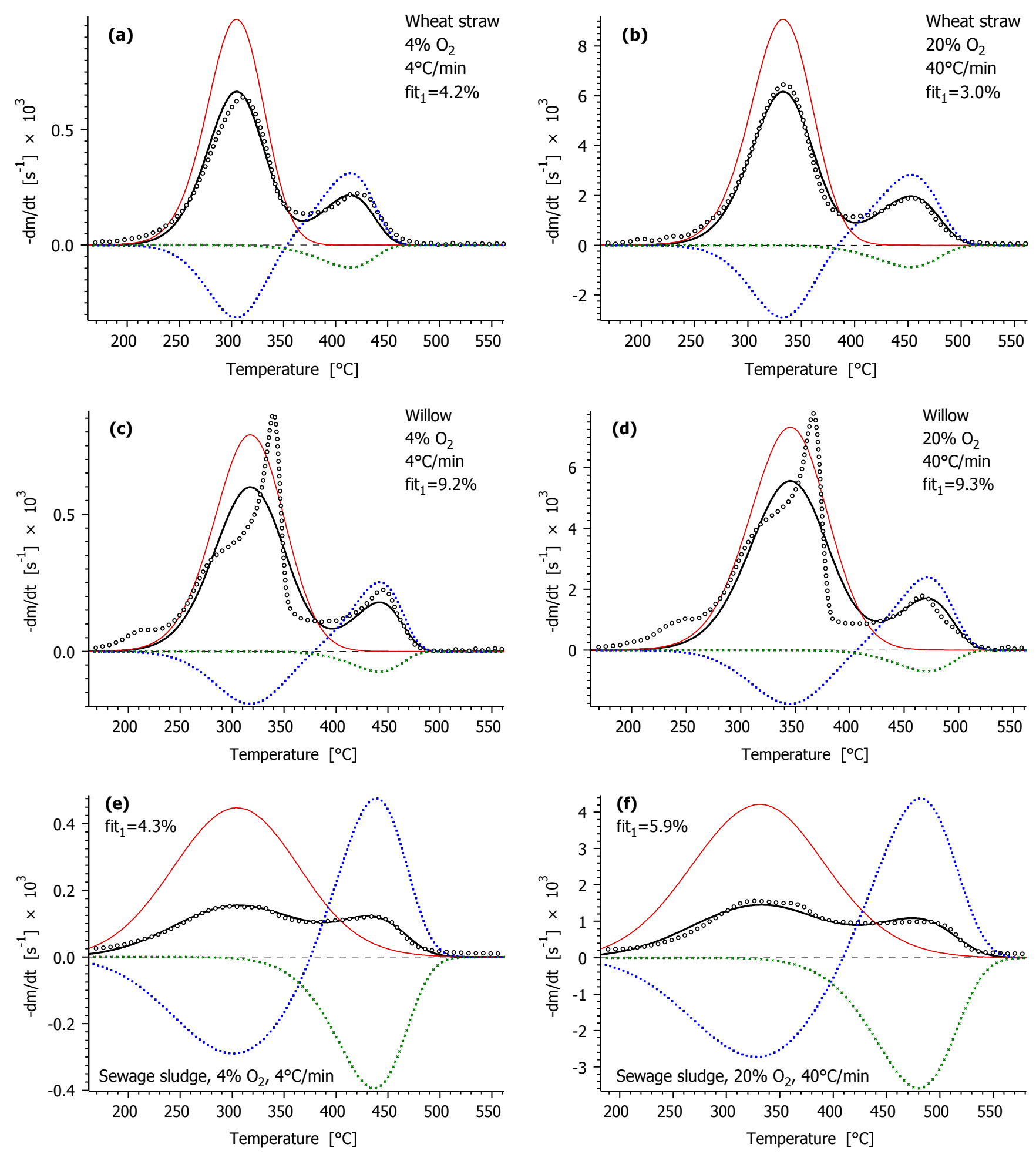

Figure 3. Evaluation by a model of successive devolatilization and char burn-off reactions. The experiments with $4^{\circ} \mathrm{C} / \mathrm{min}$ at $C_{\mathrm{O}_{2}}=0.04$ and $40^{\circ} \mathrm{C} / \mathrm{min}$ at $C_{\mathrm{O}_{2}}=0.2$ are displayed. (See the Supporting Information for more complete figures.) Notation: experimental DTG curves normalized by the initial sample mass (०); their calculated counterpart (一); and simulated partial curves $-\mathrm{d} m_{\mathrm{ur}} / \mathrm{d} t($ red -); $\mathrm{d} m_{\text {char }} / \mathrm{d} t$ (blue $\left.\cdots\right)$; and - $\mathrm{d} m_{\text {ash }} / \mathrm{d} t($ green $\times \times \times)$. 
As Figure 3 indicates, good approximations were obtained for wheat straw and sewage sludge. Note that the fit quality is characterized by quantities normalized by the peak maxima of each experiment. This is inevitable for comparing experiments with strongly different temperature programs. (See the very different scaling of the plots.) Hence fit $t_{1}$ and $f_{i t} t_{10}$ are relative precisions. In this respect the fit on the wheat straw experiments look better than the fit on the sewage sludge experiments. However, the sewage sludge decompose with flat, wide mass-loss rates, and the corresponding peak maximum is roughly a sixth of the value observed at wheat straw at a given temperature program. Accordingly the absolute precision of the approximation is better for the sewage sludge.

Note that the fit quality of the willow sample is not satisfactory and the simulated $-\mathrm{d} m / \mathrm{d} t$ curves do not mimic the features of the DTG curves in the willow plots of Figure 3. In the case of wood samples the cellulose and hemicellulose peaks do not merge; they appear as separate, partly overlapping peaks. This is due to the low mineral content of the woods; the catalytic effect of the minerals on the biomass components is well known. Accordingly a more detailed kinetics is needed for the willow sample.

3.3. Adding cellulose decomposition kinetics to the successive model. As mentioned above, the partly separated cellulose peak of the willow sample requires an additional kinetic equation for the cellulose component. Hence the unreacted part of the sample, $m_{\mathrm{ur}}$ will be regarded as the sum of the cellulose component and the rest of the sample. As mentioned earlier, $m_{\mathrm{ur}}(t)$ is normalized to unity: $m_{\mathrm{ur}}(0)=1$. The models for pyrolysis kinetics are usually written for variables normalized to the $[0,1]$ interval; accordingly we shall use reacted fractions for cellulose, $\alpha_{\text {cell }}(t)$, and for the other components of the biomass, $\alpha_{\text {other }}(t)$, with boundary conditions $\alpha_{\text {cell }}(0)=0, \alpha_{\text {cell }}(\infty)=1, \alpha_{\text {other }}(0)=0$ and $\alpha_{\text {other }}(\infty)=1$. Here the end values follow from the definition of the "unreacted": as the biomass transforms to char, the unreacted components are completely consumed. Accordingly $m_{\mathrm{ur}}(t)$ is the weighted sum of its two constituents with weight factors $c_{\text {cell }}$ and $c_{\text {other: }}$ :

$$
\begin{aligned}
& m_{\mathrm{ur}}(t)=c_{\text {cell }}\left[1-\alpha_{\text {cell }}(t)\right]+c_{\text {other }}\left[1-\alpha_{\text {other }}(t)\right], \quad c_{\text {cell }}+c_{\text {other }}=1 \\
& -\mathrm{d} m_{\mathrm{ur}} / \mathrm{d} t=c_{\text {cell }} \mathrm{d} \alpha_{\text {cell }} / \mathrm{d} t+c_{\text {other }} \mathrm{d} \alpha_{\text {other }} / \mathrm{d} t
\end{aligned}
$$


Both the cellulose and the non-cellulosic parts of the biomass form char hence eq. 9 is modified now by taking this into account:

$$
\mathrm{d} m_{\text {char }} / \mathrm{d} t=c_{\text {cell }} \mathrm{d} \alpha_{\text {cell }} / \mathrm{d} t y_{\text {cell.char }}+c_{\text {other }} \mathrm{d} \alpha_{\text {other }} / \mathrm{d} t y_{\text {other_char }}-A_{\text {char }} \exp \left(-E_{\text {char }} / \mathrm{RT}\right) m_{\text {char }} C_{O_{2}}^{v_{\text {char }}}
$$

Here $1-\alpha_{\text {other }}(t)$ is described by a DAEM, in the same way as $\mathrm{d} m_{\mathrm{ur}} / \mathrm{d} t$ was in the previous section. The cellulose decomposition in inert atmosphere can be usually approximated by simple first order kinetics. When the biomass pyrolysis is described by parallel DAEMs and the evaluation is carried out on series of experiments with strongly different temperature program, the $\sigma$ distribution parameter of the cellulose component is small or zero. ${ }^{12,13,20}$ Note that a DAEM with Gaussian distribution converges to first order kinetics as $\sigma \rightarrow 0$. It becomes exactly a first order reaction at $\sigma=0$ because the Gaussian distribution is a Dirac delta function. This happened in the present case, too: when $\alpha_{\text {cell }}(t)$ was approximated by first order kinetics, the corresponding $\sigma$ proved to be zero. However, the simulated cellulose peaks were not as sharp as their observed counterparts. It was concluded that cellulose decomposes with a selfaccelerating kinetics, where the term "self accelerating" means: the reaction rate of a unit mass of reactant is increasing in a considerable part of the reaction even if $\mathrm{T}$ is constant.

Note that Capart et al. have already reported self-accelerating cellulose pyrolysis kinetics in inert gas flow. ${ }^{24}$ They used a variant of the Prout - Tompkins equation which is equivalent to an earlier equation used by Várhegyi et al for char burn-off kinetics in $1996 .^{25}$ We shall use here this equation with the following notation:

$$
\mathrm{d} \alpha_{\text {cell }} / \mathrm{d} t=C_{O_{2}}^{v_{\text {cell }}} A_{\text {cell }} \exp \left(-E_{\text {cell }} / R T\right) f\left(\alpha_{\text {cell }}\right)
$$

where $f$ is a function capable to express self-acceleration. Note that the mathematical unambiguity requires a normalization for $f\left(\alpha_{\text {cell }}\right)$ because $f$ functions differing only in constant multipliers are equivalent in eq. 13 (parameter $A_{\text {cell }}$ can compensate any multipliers of $f$ ). As a normalization, we may require that the maximum of $f$ be $1 . f\left(\alpha_{\text {cell }}\right)$ is approximated formally by

$$
f\left(\alpha_{\text {cell }}\right) \cong \text { normfactor }\left(1-\alpha_{\text {cell }}\right)^{n_{\text {cell }}}\left(\alpha_{\text {cell }}+z\right)^{a}
$$


where $n_{\text {cell }}, a$ and $z$ are model parameters and normfactor ensures that $\max f=1$. normfactor is a simple function of $n_{\text {cell, }} a$ and $z .^{25}$ Parameters $n_{\text {cell, }} a$ and $z$ do not have separate physical meaning; together however they determine the shape of $f$, and, in this way, the self accelerating capabilities of the model. Note that eq. 14 is equivalent to a kinetics of $n_{\text {cell }}$ order at $a=0$. The n-order kinetics also can describe a moderate self-accelerating if $n_{\text {cell }}$ is less than 1. The corresponding calculations resulted in $n_{\text {cell }}=0.4$. However, the $a \neq 0$ case gave considerably better fit quality and the corresponding cellulose partial curves had more realistic shapes. The results are illustrated by Figure 4. In this evaluation 17 parameters were determined from 10 experiments: $c_{\text {cell }} / c_{\text {other }}, E_{\text {cell }}, n_{\text {cell }}, a_{\text {cell }}, z_{\text {cell }}, A_{\text {cell }}, v_{\text {cell }}, y_{\text {cell.char }}, E_{0}, \sigma$, $A_{\text {devol}}, v_{\text {devol}}, y_{\text {other_char, }} E_{\text {char }}, A_{\text {char }}, v_{\text {char }}, y_{\text {ash }}$. Most of the obtained parameter values are listed in Section 3.7, together with the parameters obtained from the other approaches considered. The shape of the obtained $f\left(\alpha_{\text {cell }}\right)$ function is shown by the red solid line in Figure 5.
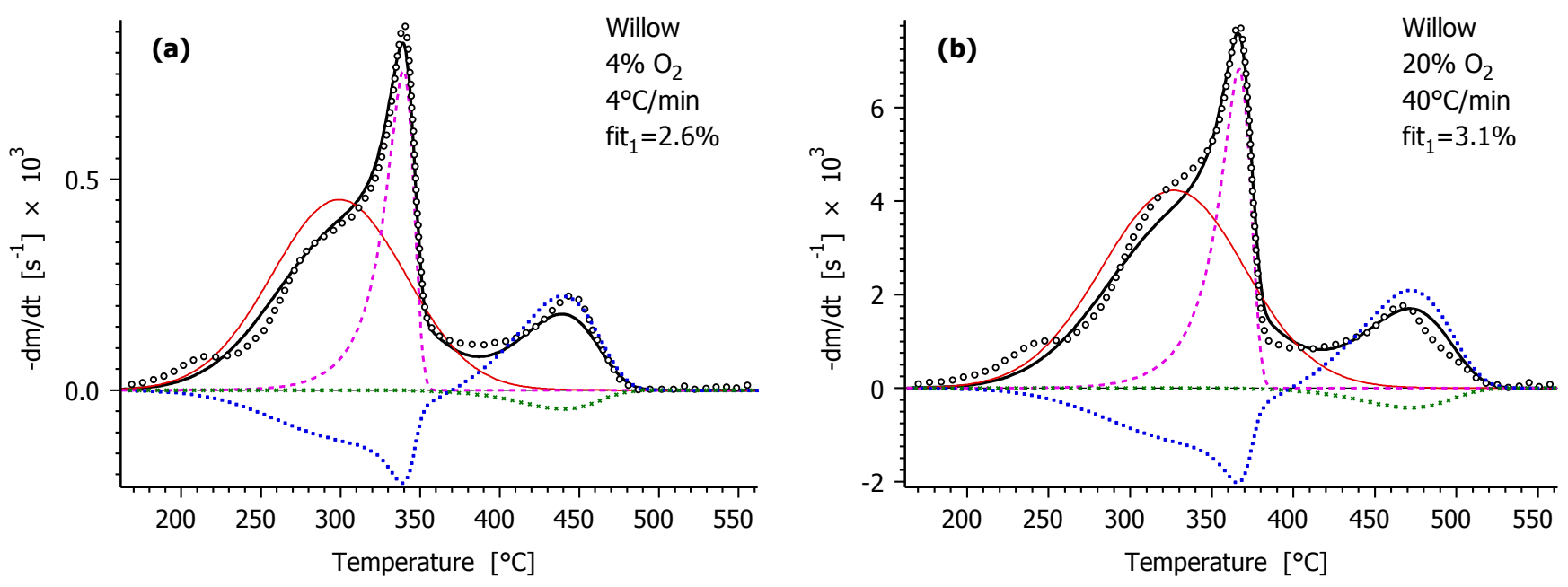

Figure 4. Evaluation by two devolatilization processes and a subsequent char burn-off reaction. Two of the evaluated ten experiments are displayed here. The devolatilization of the cellulose component and the rest of the biomass are represented by dashed lines of magenta color and red solid lines, respectively. See the rest of the notations in the legend of Figure 3. 


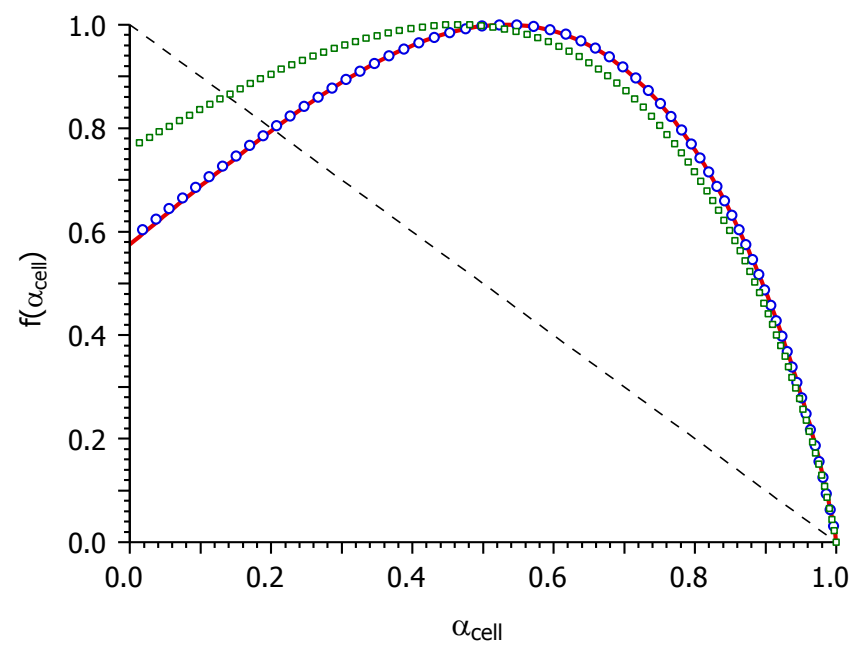

Figure 5. The reactivity functions of the oxidative cellulose pyrolysis as determined from the evaluations of Sections 3.3 (red -), 3.4 (blue o०o) and 3.5 (green ㅁo).

\subsection{Approximating the successive kinetics by a model of independent parallel reactions. In 1989}

Várhegyi et al. studied biomass pyrolysis kinetics by multistep models. ${ }^{26}$ The evaluations were carried out by the method of least squares. One of the conclusions of this early paper was: "The assumption of independent parallel reactions and the assumption of successive reactions gave roughly identical fits and kinetic parameters at the majority of the experiments; hence, the distinction between these models could only be based on chemical considerations." Later Branca and Di Blasi described the combustion of beech wood by four consecutive reactions as well as by four independent parallel reactions and observed nearly identical results for the two approaches. ${ }^{27}$ They concluded that "Activation energies, preexponential factors and reaction order of the combustion rate for char appear to be invariant with the heating rate and the selection of series or parallel reactions. Moreover, relatively small variations on the stoichiometric coefficients are required to take into account the different structure of the reaction network."

Based on these observations the models of the present work were also approximated by independent parallel reactions. In these test evaluations the char is regarded as a component (or pseudocomponent) instead of an intermediate product. In other words we imagine a char component in the biomass that starts to burn off when the temperature reaches a sufficiently high value. The consumption of the char 
component is described via its reacted fraction, $\alpha_{\text {char }}(t): \alpha_{\text {char }}(0)=0$ and $\alpha_{\text {char }}(\infty)=1$. The reacted fractions $\alpha_{\text {cell }}(t)$ and $\alpha_{\text {other }}(t)$ have already been defined in the previous section, though the physical meaning of $\alpha_{\text {other }}$ will be slightly modified, as follows.

Equations 5 and 11 are replaced by

$$
\begin{aligned}
& m^{\text {calc }}=c_{\text {char }}\left(1-\alpha_{\text {char }}\right)+c_{\text {other }}\left(1-\alpha_{\text {other }}\right)+m_{\infty} \\
& m^{\text {calc }}=c_{\text {char }}\left(1-\alpha_{\text {char }}\right)+c_{\text {cell }}\left(1-\alpha_{\text {cell }}\right)+c_{\text {other }}\left(1-\alpha_{\text {other }}\right)+m_{\infty}
\end{aligned}
$$

In eq. $15 \alpha_{\text {other }}$ describes the reacted fraction of the biomass without the imaginary char component. In eq. $16 \alpha_{\text {other }}$ means the reacted fraction of the biomass without the cellulose and the char components. $m_{\infty}=m^{\text {calc }}(\infty)$ is the predicted ash yield after the complete burn-off. A $c$ weight factor is the contributions of the given component/pseudocomponent to the overall mass loss of the sample normalized by the initial sample mass. The overall normalized mass loss, as given by the model, is obviously the difference between the initial and final values of $m^{\text {calc }}$, i.e. $1-m_{\infty}$. This value is composed from the contributions of the components, $c_{\text {char }}+c_{\text {other }}$ in eq. 15 and $c_{\text {char }}+c_{\text {cell }}+c_{\text {other }}$ in eq. 16.

$\alpha_{\text {other }}(t)$ and $\alpha_{\text {cell }}(t)$ are calculated from the same equations as in the previous sections. Equations 9 and 12, however, become simpler because the char formation terms are missing in the present approximation:

$$
\mathrm{d} \alpha_{\text {char }} / \mathrm{d} t=A_{\text {char }} \exp \left(-E_{\text {char }} / \mathrm{RT}\right)\left(1-\alpha_{\text {char }}\right) C_{O_{2}}^{v_{\text {char }}}
$$



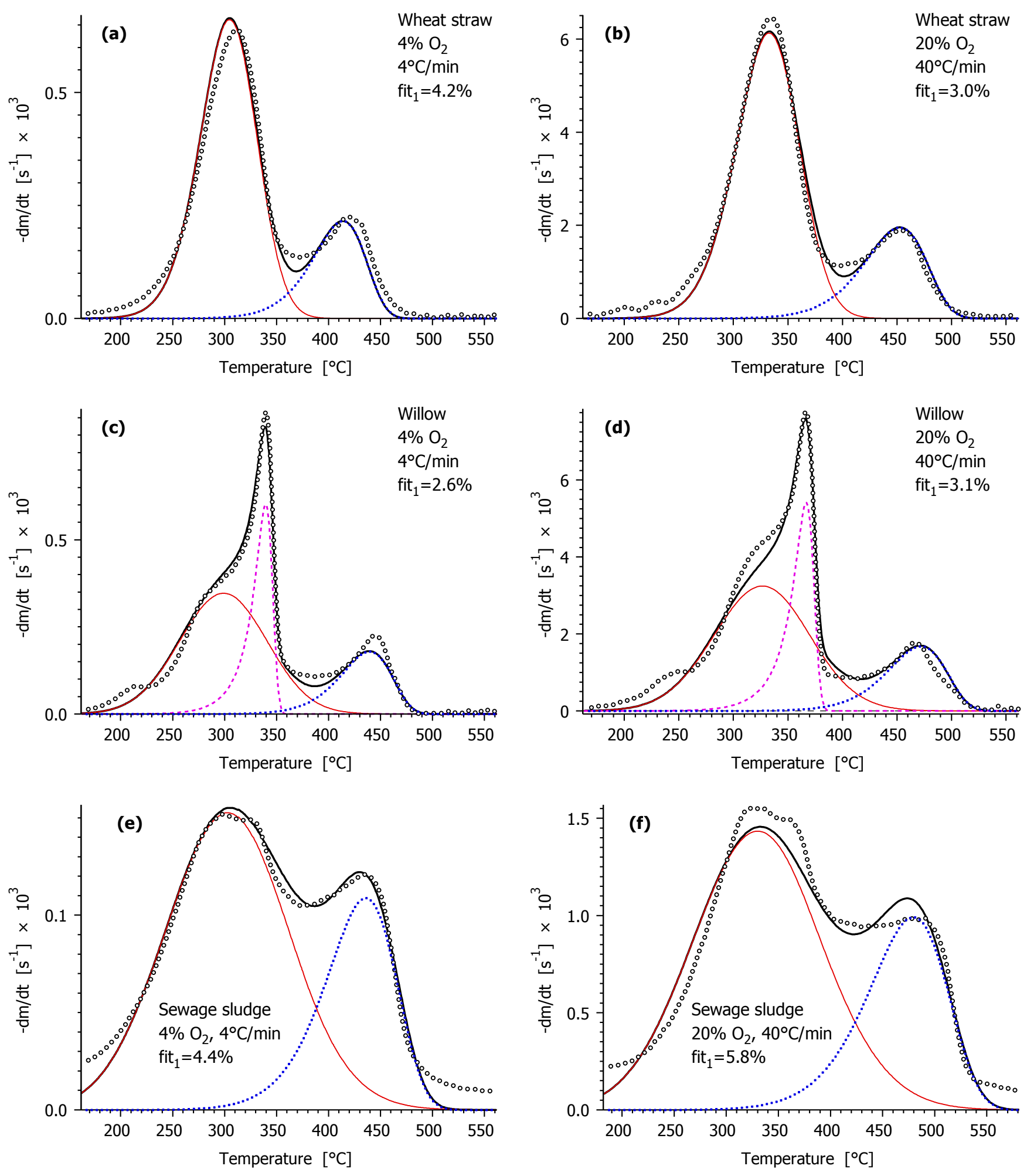

Figure 6. Approximating the subsequent char burn-off by an independent parallel reaction in the model. The experiments with $4{ }^{\circ} \mathrm{C} / \mathrm{min}$ at $\mathrm{C}_{\mathrm{O}_{2}}=0.04$ and $40^{\circ} \mathrm{C} / \mathrm{min}$ at $\mathrm{C}_{\mathrm{O}_{2}}=0.2$ are displayed. Notations: $\mathrm{d} m^{\text {obs }} / \mathrm{d} t(\circ) ;-\mathrm{d} m^{\text {calc }} / \mathrm{d} t(-)$; and simulated partial curves: $c_{\text {other }} \mathrm{d} \alpha_{\text {other }} / \mathrm{d} t($ red -$) ; c_{\text {cell }} \mathrm{d} \alpha_{\text {cell }} / \mathrm{d} t$ (magenta --); and $c_{\text {char }} \mathrm{d} \alpha_{\text {char }} / \mathrm{d} t$ (blue -..). 
As Figure 6 reflects, practically the same fit qualities were obtained in this way as in the wheat straw and sewage sludge models of Section 3.2 (plots a, b, e, f in Figures 3) and in the willow model of Section 3.3 (Figure 4). The overall fit qualities (fit $t_{10}$ ) and the obtained kinetic parameters are also very similar, as will be shown in Section 3.7. The function defining the self-acceleration of the oxidative cellulose decomposition, $f\left(\alpha_{\text {cell }}\right)$ was also nearly identical in the two cases, as the red line and the blue circles show in Figure 5.

Accordingly the approximation of the char burn-off by an independent parallel reaction is a viable method. Its advantage is the easier solution of the corresponding kinetic equation: the solution of eq. 17 needs a simpler numerical algorithm than that of equations 9 and 12 . The drawback of this modeling is some loss in the physical meaning of the model.

3.5. Replacing the DAEM by simpler kinetics. Here another simplification will be examined: the distributed activation energy model for the devolatilization (equations 6 - 8) is replaced by simpler, norder kinetics:

$$
-\mathrm{d} m_{\mathrm{ur}} / \mathrm{d} t==C_{O_{2}}^{v_{\text {devol }}} A_{\text {devol }} \mathrm{e}^{-E / R T} m_{u r}^{n_{u r}}
$$

The rest of the model is not changed: the char burn-off is a subsequent reaction described by equation 9 or 12 , and the cellulose component of the wood sample is described by equations 13-14.

Using the notation of Section 3.3 eq. 18a will have the following form:

$$
\mathrm{d} \alpha_{\text {other }} / \mathrm{d} t=C_{O_{2}}^{v_{\text {devol }}} A_{\text {devol }} \mathrm{e}^{-E / R T}\left(1-\alpha_{\text {other }}\right)^{n_{\text {other }}}
$$

The fit quality of this model was not as good as the values obtained with DAEM devolatilization. Figure 7 shows part of the experiments of the series evaluated. Besides, highly asymmetric devolatilization peaks (red lines in Figure 7) arose in the case of willow and sewage sludge. The asymmetry and tailing of these peaks are due to their high reaction orders, 3.7 and 4.3, respectively. Similarly high reaction orders were reported in the literature, too. Manyà at al. emphasized that a reaction order of 3 is advantageous for describing the lignin kinetics in a biomass pyrolysis model of three parallel reactions. ${ }^{28}$ Recently Conesa and Domene studied the kinetics of biomasses pyrolysis and 
combustion through n-order parallel reactions and found high reaction orders, up to 9.5. ${ }^{29}$ Barneto et al. presented a kinetic model for biomass combustion which have some similarities to the models treated in the present section. ${ }^{30}$ They assumed two biomass components, holocellulose (hemicelluloses and cellulose together) and lignin that decompose by n-order kinetics. The formed chars burn-off in subsequent reactions. However, the corresponding kinetic equations did not express the reaction rates of these chars as the difference between the char formation and char burn-off rates. (There were no separate terms for the char formation and char burn-off in the ordinary differential equations for the chars.) This is a significant difference from the models of the present work. The reaction order of the lignin decomposition was 3.3, in the work of Barneto et al. ${ }^{30}$

It is hard to form an opinion on the meaning of the high reaction orders in the cited works. It is probably a convenient way to describe the slow charring in inert ambient, as Manyà at al. highlighted. ${ }^{28}$ In the present work, however, the highly asymmetric decomposition peaks invalidate the physical meaning of the model. The long, high tailing section of the red colored devolatilization peak in the sewage sludge plots overlaps with the char burn-off peak and extends to temperatures above the domain of the char burn-off. The situation is similar, though less expressed in the case of the willow plots in Figure 3. 

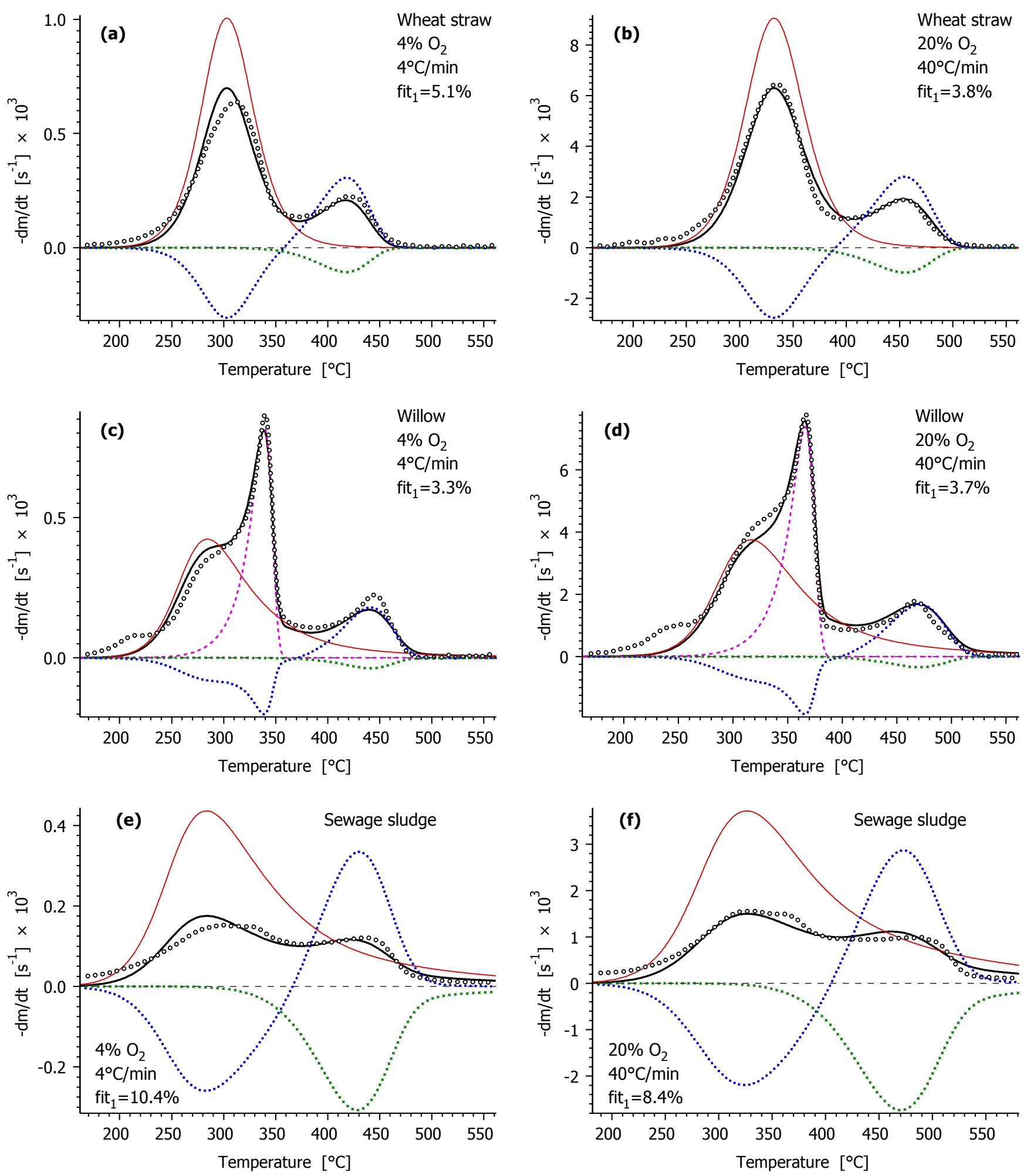

Figure 7. Replacing the distributed activation energy devolatilization model by simpler n-order kinetics, as outlined in Section 3.5. The experiments with $4{ }^{\circ} \mathrm{C} / \mathrm{min}$ at $C_{\mathrm{O}_{2}}=0.04$ and $40^{\circ} \mathrm{C} / \mathrm{min}$ at $C_{\mathrm{O}_{2}}=0.2$ are displayed. Notations: $-\mathrm{d} m^{\mathrm{obs}} / \mathrm{d} t(\circ) ;-\mathrm{d} m^{\mathrm{calc}} / \mathrm{d} t$ (一); and simulated partial curves: $c_{\text {other }} \mathrm{d} \alpha_{\text {other }} / \mathrm{d} t($ red - $) ; c_{\text {cell }} \mathrm{d} \alpha_{\text {cell }} / \mathrm{d} t$ (magenta ---); and $c_{\text {char }} \mathrm{d} \alpha_{\text {char }} / \mathrm{d} t$ (blue -..). 
The fit quality in the sewage sludge evaluation can obviously be improved by assuming more than one n-order devolatilization reactions, like in the case of the willow evaluation. There is a difference, however, in the behaviors of the two samples. The DTG curves of the willow sample show characteristic features: a separated cellulose peak and a clearly visible hemicelluloses shoulder. These features provide enough information to determine the parameters of the two devolatilization peaks during the least squares evaluation of a series of experiments. This is not so with the flat, featureless devolatilization peak of the sewages sludge experiments at linear $\mathrm{T}(\mathrm{t})$. The evaluation of the sewage sludge experiments with two devolatilization processes and a subsequent char burn-off proved to be an ill-defined problem: the available experimental information was not enough to find a unique, meaningful solution. Besides, a model with two n-order devolatilization steps should be compared to its counterpart with two DAEM devolatilization reactions, so that the compared models should contain the same number of parameters. Test calculations were carried out that showed that the DAEM devolatilization provided better fit quality and peaks with less tailing in this case, too.

3.6. Experience with more complex char burn-off kinetics. In the case of ideal chars (specially prepared, pure model carbons) the reaction rate is proportional to the surface area. If the reaction takes place on the external surface, $n$-order models can be used with $n<1$, where $n=2 / 3$ for spherical particles (contracting sphere model) and $\mathrm{n} \approx 1 / 2$ for needle-shaped particles (contracting area model). ${ }^{31}$ The presence of internal surfaces (pores that grow during the burn off) results in a strong acceleration. In ideal cases the corresponding change of the surface area during the reaction can be described by theoretical models. ${ }^{32,33}$

In the case of a biomass fuel, however, complicating factors arise that are connected to the accessibility of the internal pores, the role of the inorganic catalysts, and the chemical/physical inhomogeneity of the solid phase. Among others, the char formation is not separated from the char burn-off; the formed char particles may burn before developing a bulk with internal pores. On the other hand the different fractions of the biomass may result in chars of different reactivity and the reactivity 
differences may widen the mass loss rate curve of the char burn-off. Keeping the above factors in mind we tried to replace the first order char burn-off kinetics by empirical models that can mimic either selfaccelerations due to pore formation or a widening due to char inhomogeneity. The simplest model for that purpose is the n-order kinetics. If $n<1$, the process accelerates because the rate of a unit mass of reaction, $\frac{-d m / d t}{m}$ is increasing when $\mathrm{T}$ does not change. If $\mathrm{n}>1, \frac{-d m / d t}{m}$ is decreasing at constant $\mathrm{T}$, mimicking the existence of more and less reactive parts in the char. In equations 9 and 12 the char burnoff rate is replaced by

$$
A_{\text {char }} \exp \left(-E_{\text {char }} / \mathrm{RT}\right) m_{\text {char }}^{n_{\text {char }}} C_{O_{2}}^{v_{\text {char }}}
$$

When the char burn-off is approximated by parallel reactions, equation (17) is replaced by

$$
\mathrm{d} \alpha_{\text {char }} / \mathrm{d} t=A_{\text {char }} \exp \left(-E_{\text {char }} / \mathrm{RT}\right)\left(1-\alpha_{\text {char }}\right)^{n_{\text {char }}} C_{O_{2}}^{v_{\text {char }}}
$$

The use of equations 19 and 20 did not improve the fit quality for the willow and sewage sludge samples, the corresponding $n_{\text {char }}$ values were around 1. A rather slight improvement was observed for the wheat straw samples, where $f_{i t} t_{10}$ decreased from $3.99 \%$ to $3.90 \%$ and the obtained reaction order, $n_{\text {char }}$ was 1.31.

The next step was the replacement of the n-order kinetics by more complex $f\left(m_{\text {char }}\right)$ or $f\left(\alpha_{\text {char }}\right)$ functions in equations 19 and 20, respectively. The empirical formula of eq. 14 was employed, which had proved to be useful in char burning studies. ${ }^{17,25}$ Despite the higher number of model parameters, however, the fit quality was not considerably better than in the case of the 1st order and n-order kinetics. Recently a model was proposed that assumed pore formation during the devolatilization, hence the acceleration was expressed through the conversion of the entire sample. ${ }^{15}$ This approach was also tried without any considerable improvement. Finally the char burn-off was tried to be described by DAEM kinetics, assuming fractions of different reactivity in the char phase. This approach was carried out in the parallel model only, and has not provided mentionable improvement for the willow and sewage sludge samples. The corresponding parameter for the distribution width, $\sigma_{\text {char }}$ had small values, 0 and 2 
$\mathrm{kJ} / \mathrm{mol}$, respectively, indicating first order or nearly first order reactions. In the case of wheat straw $\sigma_{\text {char }}$ was $3.6 \mathrm{~kJ} / \mathrm{mol}$, while the fit quality and the model parameters were very close to the values obtained by n-order char kinetics. (The fit values and model parameters will be listed and discussed in the next section.) The closeness of these results suggests that both the the n-order kinetics with $n_{\text {char }}>1$ and the DAEM approximate the same a char inhomogeneity in this case. Nevertheless, the improvement of the fit is negligible, as mentioned above; the first order kinetics with respect to the amount of char is a suitable model for the samples of the present studies.

3.7. Comparison of the parameters obtained from the different model variants. For a comparison of the model parameters we need the connections between the yield parameters of the successive models and the $c$ weight factors of the parallel reactions. In eq. 15 the mass loss due to the devolatilization is $c_{\text {other }}$, hence the yield of the solid residue (char) from the devolatilization is

$$
y_{\text {char }}=1-c_{\text {other }}
$$

The normalized amount of volatiles formed from the char is $c_{\text {char }}$, the normalized amount of ash forming from the sample is $m_{\infty}=1-c_{\text {char }}+c_{\text {other }}$, as follows directly from eq. 15 at $\mathrm{t}=0$. Hence the ash yield of the char fraction, $y_{\text {ash }}$ is

$$
y_{\text {ash }}=\frac{m_{\infty}}{y_{\text {char }}}=\frac{1-c_{\text {char }}-c_{\text {other }}}{1-c_{\text {other }}}
$$

In the case of the wood sample, the biomass devolatilization is split to that of the cellulose and the other biomass component. The $c$ coefficients of the parallel model in eq. 16 do not tell anything about the separate char yields of the cellulose and the rest of the biomass. However a global $y_{\text {char }}$ can be determined in the way outlined above. The normalized mass loss due to the devolatilization is $c_{\text {cell }}{ }^{+}$ $c_{\text {other }}$, hence

$$
y_{\text {char }}=1-c_{\text {cell }}-c_{\text {other }}
$$

and the ash yield of the char fraction, $y_{\text {ash }}$ is 


$$
y_{\text {ash }}=\frac{m_{\infty}}{y_{\text {char }}}=\frac{1-c_{\text {char }}-c_{\text {cell }}-c_{\text {other }}}{1-c_{\text {cell }}-c_{\text {other }}}
$$

When the parameters of the successive model variants are compared to those of the entirely parallel models, the counterpart of $y_{\text {char }}$ can be calculated as the weighted average of $y_{\text {cell.char }}$ and $y_{\text {other_char. }}$.

Tables 4-7 summarize the parameters for six of the model variants treated in this work. Some of the listed values serve only for comparison, as outlined above. The actual number of the parameters determined in the evaluation, $N_{\text {parameters, }}$ is indicated in the last rows of Tables $4-7$. It is interesting to note that the columns contain similar values in each of these tables. The only notable exceptions are the models with n-order devolatilization (the last columns in Tables 4 - 7) where the fit quality is worse and the activation energy of the devolatilization is lower than in the other models presented. Tables 4-7 do not rank the model variants with DAEM devolatilization; they are practically equivalent to each other. One should use other considerations for selecting the right model variant. In our opinion the models with successive char burn-off reactions can be recommended because their meaning is clearer than that of their counterparts with parallel kinetics, and they give predicted reaction rates on the char and ash formation.

The obtained activation energy and $v$ values are within the usual ranges of the studies listed in the references. It may be worth considering why the $v_{\text {char }}$ values are less then unity. Note that care was taken to ensure a true kinetic regime in the present work: low sample masses were spread in thin layers, the heating rates were not high and the formed $\mathrm{CO}$ and $\mathrm{CO}_{2}$ were quickly swept away from the combusting samples. Accordingly the values of $0.5-0.7$ cannot be due to diffusion control or to reversible reactions. They only indicate that the oxygen concentration is not the only rate determining factor in the kinetics. 
Table 4. Comparison of the model parameters obtained for wheat straw sample

\begin{tabular}{|c|c|c|c|c|c|c|}
\hline Devolatilization & DAEM & DAEM & DAEM & DAEM & DAEM & n-order \\
\hline $\begin{array}{l}\text { Char } \\
\text { burn-off }\end{array}$ & $\begin{array}{l}\text { succes- } \\
\text { sive } \\
1^{\text {st }} \text { order }\end{array}$ & $\begin{array}{l}\text { succes- } \\
\text { sive } \\
\text { n order }\end{array}$ & $\begin{array}{l}\text { parallel } \\
1^{\text {st }} \text { order }^{\mathrm{a}}\end{array}$ & $\begin{array}{l}\text { parallel } \\
\text { n order }\end{array}$ & $\begin{array}{l}\text { parallel } \\
\text { DAEM }^{\mathrm{a}}\end{array}$ & $\begin{array}{l}\text { succes- } \\
\text { sive } \\
1^{\text {st }} \text { order }\end{array}$ \\
\hline fit $_{10}(\%)$ & 3.99 & 3.90 & 3.99 & 3.90 & 3.89 & 4.55 \\
\hline$E_{0} / \mathrm{kJ} \mathrm{mol}^{-1}$ & 157 & 157 & 157 & 157 & 157 & 150 \\
\hline$\sigma / \mathrm{kJ} \mathrm{mol}^{-1}$ & 5.5 & 5.5 & 5.5 & 5.5 & 5.5 & - \\
\hline$n_{\text {devol }}$ & - & - & - & - & - & 1.92 \\
\hline $\log _{10} A_{\mathrm{devol}} / \mathrm{s}^{-1}$ & 12.24 & 12.27 & 12.23 & 12.27 & 12.25 & 11.75 \\
\hline$v_{\text {devol }}$ & 0.43 & 0.43 & 0.43 & 0.43 & 0.43 & 0.42 \\
\hline$y_{\text {char }}$ & 0.32 & 0.32 & 0.33 & 0.33 & 0.33 & 0.31 \\
\hline$E_{\text {char }} / \mathrm{kJ} \mathrm{mol}^{-1}$ & 151 & 161 & 151 & 161 & 162 & 160 \\
\hline$\sigma_{\mathrm{char}} / \mathrm{kJ} \mathrm{mol}^{-1}$ & - & - & - & - & 3.6 & - \\
\hline$n_{\text {char }}$ & 1 & 1.31 & 1 & 1.31 & - & 1 \\
\hline $\log _{10} A_{\text {char }} / \mathrm{s}^{-1}$ & 9.56 & 10.53 & 9.53 & 10.38 & 10.44 & 10.20 \\
\hline$v_{\text {char }}$ & 0.50 & 0.52 & 0.50 & 0.53 & 0.54 & 0.51 \\
\hline$y_{\text {ash }}$ & 0.31 & 0.28 & 0.31 & 0.28 & 0.28 & 0.35 \\
\hline$N_{\text {parameters }}$ & 9 & 10 & 9 & 10 & 10 & 9 \\
\hline
\end{tabular}

${ }^{\mathrm{a}} y_{\text {char }}$ and $y_{\text {ash }}$ are calculated from the $c$ coefficients by equations 19 and 20, respectively, for the parallel model variants. 
Table 5. Comparison of the model parameters obtained for the willow sample ${ }^{a}$

\begin{tabular}{|c|c|c|c|c|c|c|}
\hline Devolatilization & DAEM & DAEM & DAEM & DAEM & DAEM & n-order \\
\hline $\begin{array}{l}\text { Char } \\
\text { burn-off }\end{array}$ & $\begin{array}{l}\text { succes- } \\
\text { sive } \\
1^{\text {st }} \text { order }^{\text {b }}\end{array}$ & $\begin{array}{l}\text { succes- } \\
\text { sive } \\
\text { n order }\end{array}$ & $\begin{array}{l}\text { parallel } \\
1^{\text {st }} \text { order }^{\mathrm{c}}\end{array}$ & $\begin{array}{l}\text { parallel } \\
\text { n order }\end{array}$ & $\begin{array}{l}\text { parallel } \\
\text { DAEM }^{c}\end{array}$ & $\begin{array}{l}\text { succes- } \\
\text { sive } \\
1^{\text {st }} \text { order }^{\mathrm{b}}\end{array}$ \\
\hline fit $_{10}(\%)$ & 4.21 & 4.20 & 4.20 & 4.20 & 4.20 & 4.97 \\
\hline$E_{\text {cell }} / \mathrm{kJ} \mathrm{mol}^{-1}$ & 145 & 145 & 145 & 145 & 145 & 147 \\
\hline $\log _{10} A_{\text {cell }} / \mathrm{s}^{-1}$ & 10.66 & 10.66 & 10.66 & 10.66 & 10.66 & 10.78 \\
\hline$E_{0} / \mathrm{kJ} \mathrm{mol}^{-1}$ & 166 & 166 & 166 & 166 & 166 & 142 \\
\hline$\sigma / \mathrm{kJ} \mathrm{mol}^{-1}$ & 11.2 & 11.2 & 11.2 & 11.2 & 11.2 & - \\
\hline$n_{\text {devol }}$ & - & - & - & - & - & 3.70 \\
\hline $\log _{10} A_{\mathrm{devol}} / \mathrm{s}^{-1}$ & 13.05 & 13.04 & 13.06 & 13.04 & 13.06 & 11.28 \\
\hline$v_{\text {cell }}$ & 0.61 & 0.61 & 0.61 & 0.61 & 0.61 & 0.61 \\
\hline$v_{\text {devol }}$ & 0.37 & 0.37 & 0.37 & 0.37 & 0.37 & 0.31 \\
\hline$y_{\text {cell.char }}$ & 0.21 & 0.21 & - & - & - & 0.21 \\
\hline$y_{\text {other_char }}$ & 0.23 & 0.23 & - & - & - & 0.17 \\
\hline$y_{\text {char }}$ & 0.22 & 0.22 & 0.23 & 0.22 & 0.23 & 0.18 \\
\hline$c_{\text {cell }} / c_{\text {other }}$ & 0.44 & 0.43 & 0.44 & 0.44 & 0.44 & 0.57 \\
\hline$E_{\text {char }} / \mathrm{kJ} \mathrm{mol}^{-1}$ & 169 & 167 & 169 & 167 & 169 & 176 \\
\hline$\sigma_{\text {char }} / \mathrm{kJ} \mathrm{mol}^{-1}$ & - & - & - & - & 0 & - \\
\hline$n_{\text {char }}$ & 1 & 0.95 & 1 & 0.94 & - & 1 \\
\hline $\log _{10} A_{\text {char }} / \mathrm{s}^{-1}$ & 10.66 & 10.49 & 10.66 & 10.52 & 10.66 & 11.25 \\
\hline$\nu_{\text {char }}$ & 0.62 & 0.62 & 0.62 & 0.63 & 0.62 & 0.67 \\
\hline$y_{\text {ash }}$ & 0.20 & 0.20 & 0.20 & 0.20 & 0.20 & 0.20 \\
\hline$N_{\text {parameters }}$ & 17 & 18 & 16 & 17 & 17 & 17 \\
\hline
\end{tabular}

${ }^{\text {a }}$ The parameters of the $f\left(\alpha_{\text {cell }}\right)$ functions are listed and compared in the Supporting Information.

${ }^{\mathrm{b}}$ The global char yield, $y_{\text {char, }}$ is calculated as the weighted average of $y_{\text {cell.char }}$ and $y_{\text {other_char }}$ for the model variants with successive char burn-off.

${ }^{\mathrm{c}} y_{\text {char }}$ and $y_{\text {ash }}$ are calculated from the $c$ coefficients by equations 21 and 22, respectively, for the model variants with parallel char burn-off. 
Table 6. Comparison of the model parameters obtained for the sewage sludge sample

\begin{tabular}{|c|c|c|c|c|c|c|}
\hline $\begin{array}{l}\text { Devolatilization } \\
\text { Char } \\
\text { burn-off }\end{array}$ & $\begin{array}{l}\text { DAEM } \\
\text { succes- } \\
\text { sive } \\
1^{\text {st }} \text { order }\end{array}$ & $\begin{array}{l}\text { DAEM } \\
\text { succes- } \\
\text { sive } \\
\text { n order }\end{array}$ & $\begin{array}{l}\text { DAEM } \\
\text { parallel } \\
1^{\text {st }} \text { order }^{\mathrm{a}}\end{array}$ & $\begin{array}{l}\text { DAEM } \\
\text { parallel } \\
\text { n order }\end{array}$ & $\begin{array}{l}\text { DAEM } \\
\text { parallel } \\
\text { DAEM }^{\text {b }}\end{array}$ & $\begin{array}{l}\text { n-order } \\
\text { succes- } \\
\text { sive } \\
1^{\text {st }} \text { order }\end{array}$ \\
\hline$f_{i t} 10(\%)$ & 6.08 & 6.08 & 6.01 & 6.01 & 5.99 & 9.03 \\
\hline$E_{0} / \mathrm{kJ} \mathrm{mol}^{-1}$ & 143 & 143 & 143 & 143 & 144 & 102 \\
\hline$\sigma / \mathrm{kJ} \mathrm{mol}^{-1}$ & 14.4 & 14.4 & 14.1 & 14.1 & 14.0 & - \\
\hline$n_{\text {devol }}$ & - & - & - & - & - & 4.28 \\
\hline $\log _{10} A_{\mathrm{devol}} / \mathrm{s}^{-1}$ & 10.98 & 10.97 & 11.00 & 11.01 & 11.07 & 7.33 \\
\hline$\nu_{\text {devol }}$ & 0.54 & 0.54 & 0.52 & 0.52 & 0.52 & 0.35 \\
\hline$y_{\text {char }}$ & 0.66 & 0.66 & 0.67 & 0.67 & 0.67 & 0.60 \\
\hline$E_{\mathrm{char}} / \mathrm{kJ} \mathrm{mol}^{-1}$ & 120 & 120 & 120 & 121 & 122 & 112 \\
\hline$\sigma_{\text {char }} / \mathrm{kJ} \mathrm{mol}^{-1}$ & - & - & - & - & 2.0 & - \\
\hline$n_{\text {char }}$ & 1 & 1.00 & 1 & 1.03 & - & 1 \\
\hline $\log _{10} A_{\text {char }} / \mathrm{s}^{-1}$ & 7.03 & 7.03 & 7.03 & 7.07 & 7.19 & 6.38 \\
\hline$\nu_{\text {char }}$ & 0.65 & 0.65 & 0.65 & 0.65 & 0.66 & 0.73 \\
\hline$y_{\text {ash }}$ & 0.79 & 0.79 & 0.78 & 0.78 & 0.77 & 0.79 \\
\hline$N_{\text {parameters }}$ & 9 & 10 & 9 & 10 & 10 & 9 \\
\hline
\end{tabular}

${ }^{\mathrm{b}} y_{\text {char }}$ and $y_{\text {ash }}$ are calculated from the $c$ coefficients by equations 19 and 20, respectively, for the parallel model variants.

\section{Conclusions}

(1) The combustion of three common biomass materials was studied at slow heating programs, under well-defined conditions. Particularly low sample masses were employed to avoid the self-heating of the samples due to the huge reaction heat of the combustion. Ten different experiments were evaluated simultaneously for each sample by the method of least squares. Several models / model variants were tested. 
(2) A recent combustion model consisting of a devolatilization reaction and a successive char burn-off reaction was tested on biomass samples. (Earlier it was used for tobacco only.) The devolatilization step was described by a distributed activation energy model (DAEM). The combustion of the forming char was approximated by first order kinetics with respect to the amount of char. The dependence of the reactions on the oxygen concentration was described by power functions. The combustion of the volatiles was not treated in the present work. (It cannot be measured by TGA.) This model provided good description for the wheat straw and sewage sludge samples.

(3) The wood sample could not been described well by the above two-step model, because the oxidative devolatilization of the cellulose component markedly differed from that of the other biomass components. Hence an additional kinetic equation was added to describe the oxidative thermal decomposition of the cellulose component. For this purpose a self-accelerating kinetic model proved to be suitable.

(4) Earlier works with simpler models and linear temperature programs showed that the successive mechanism can be well approximated by parallel reactions. Such approximations proved to be viable for the present cases, too, when the series of experiments contained linear and stepwise temperature programs and the kinetics involved a DAEM step.

(5) The use of a successive char burn-off reaction and the approximation of the char burn-off with a parallel reaction gave practically the same fit quality and parameter values when the rest of the model assumptions were identical. The advantage of the parallel approach is the somewhat easier numerical solution of an ordinary differential equation in the model. On the other hand the assumption of an $a$ priori existing char fraction in the biomass is not realistic. The physical meaning of char formation reactions with successive char burn-off is clearer and more straightforward. Besides, the successive approach provides predictions (curves on the reaction rates or the mass) for the charcoal formation and ash formation.

(6) The model variants with first order char burn-off kinetics provided good fit quality and realistic model parameters. Nevertheless, one can expect complicating factors for the char burn-off. 
Acceleration may be caused by internal surfaces (pores). On the other hand the different fractions of the biomass may result in chars of different reactivity. To explore these aspects test evaluations were carried out where the char burn-off was described by n-order kinetics; two self-accelerating (autocatalytic) kinetic models; and by a DAEM. These approaches, however, did not improve the already good fit qualities considerably.

(7) The two-step and the three-step mechanisms treated above involved the least squares determination of 9 and 17 parameters, respectively, from a series of 10 experiments. When the necessity of more complex char burn-off kinetics was tested, the number of parameters was slightly increased. The different model variants gave essentially the same fit qualities and nearly the same values for the model parameters.

(8) The replacement of the DAEM devolatilization step by simpler n-order kinetics resulted in poorer performance of the models.

Acknowledgment. The authors thank the support of the Hungarian National Research Fund (OTKA K72710 and K81959).

Supporting Information Available: The figures of this article illustrate the kinetic evaluation by two experiments for each sample. Figures S1 - S6 of the Supporting Information show complete series of experiments evaluated simultaneously. Besides, details are given on the autocatalytic (selfaccelerating) kinetics of the oxidative decomposition of the cellulose in the wood sample of the study. This material is available free of charge via the Internet at http://pubs.acs.org.

\section{NOMENCLATURE}

$\alpha=$ reacted fraction of a component or pseudocomponent (dimensionless)

$v=$ reaction order with respect of oxygen concentration

$A=$ pre-exponential factor $\left(\mathrm{s}^{-1}\right)$

$a=$ formal parameter in eq. 14 (dimensionless) 
$C_{\mathrm{O}_{2}}=\mathrm{V} / \mathrm{V}$ concentration of the ambient oxygen (dimensionless)

$E=$ activation energy $(\mathrm{kJ} / \mathrm{mol})$ or mean activation energy in a distributed activation energy model $(\mathrm{kJ} / \mathrm{mol})$

$f=$ empirical function (eq. 14) expressing the change of the reactivity as the reactions proceed (dimensionless)

$f i t=$ a measure of the fit quality calculated for either one experiment, fit 1 , or for a series of 10 experiments, fit $10(\%)$

$h_{\mathrm{k}}=$ height of an experimental curve $\left(\mathrm{s}^{-1}\right)$

$m=$ the mass of the sample or a component of the sample normalized by the initial sample mass (dimensionless)

$n=$ reaction order (dimensionless)

$N_{\mathrm{k}}=$ number of evaluated data on the $k$ th experimental curve

$N_{\text {parameters }}=$ number of parameters determined in the evaluation of a series of experiments

$R=$ gas constant $\left(8.3143 \times 10^{-3} \mathrm{~kJ} \mathrm{~mol}^{-1} \mathrm{~K}^{-1}\right)$

$\sigma=$ width parameter (variance) of Gaussian distribution $(\mathrm{kJ} / \mathrm{mol})$

$S_{1}=$ least squares sum for one experiments (dimensionless due to normalization by the peak maximum)

$S_{10}=$ least squares sum for 10 experiments (dimensionless due to normalizations by peak maxima)

$t=$ time $(\mathrm{s})$

$T=$ temperature $\left({ }^{\circ} \mathrm{C}, \mathrm{K}\right)$

$y=$ yield (dimensionless). $y_{\text {char }}$ and $y_{\text {ash }}$ denote the char yield from biomass and the ash yield from char, respectively. $y_{\text {cell.char }}$ and $y_{\text {other_char }}$ represent the char yield from the cellulose and from the rest of the biomass, respectively.

$z=$ formal parameter in eq. 14 (dimensionless)

Subscripts:

$\mathrm{i}=$ digitized point on an experimental curve

$\mathrm{k}=$ experiment

ur $=$ unreacted sample 


\section{REFERENCES}

(1) Di Blasi, C. Modeling chemical and physical processes of wood and biomass pyrolysis. Progr. Energy Combust. Sci. 2008, 34, 47-90.

(2) Di Blasi, C. Combustion and gasification rates of lignocellulosic chars. Progr. Energy Combust. Sci. 2009, 35, 121-140.

(3) Muramatsu, M.; S. Umemura, S.; Okada, T. A mathematical model of evaporation-pyrolysis processes inside a naturally smouldering cigarette, Combust. Flame 1979, 36, 245 - 262.

(4) Burnham, A. K.; Braun, R. L. Global kinetic analysis of complex materials. Energy Fuels 1999, $13,1-22$.

(5) Avni, E.; Coughlin, R.W.; Solomon P.R., King H.H. Mathematical modelling of lignin pyrolysis. Fuel 1985, 64 1495-1501.

(6) Saidi, M. S.; Hajaligol, M. R.; Rasouli, F. Numerical simulation of a burning cigarette during puffing. J. Anal. Appl. Pyrolysis 2004, 72, 141-152.

(7) Várhegyi, G.; Szabó, P.; Antal, M. J., Jr. Kinetics of charcoal devolatilization. Energy Fuels 2002, 16, 724-731.

(8) Wójtowicz, M. A.; Bassilakis, R.; Smith, W. W.; Chen, Y.; Carangelo, R. M. Modeling the evolution of volatile species during tobacco pyrolysis. J. Anal. Appl. Pyrolysis, 2003, 66, 235-261.

(9) Yi, S-C.; Hajaligol, M. R. Product distribution from the pyrolysis modeling of tobacco particles. J. Anal. Appl. Pyrolysis, 2003, 66, 217-234.

(10) Rostami, A. A.; Hajaligol, M.R.; Wrenn, S. E. A biomass pyrolysis sub-model for CFD applications. Fuel 2004, 83, 1519-25.

(11) Yi, S-C.; Hajaligol, M. R.; Jeong, S. H. The prediction of the effects of tobacco type on smoke composition from the pyrolysis modeling of tobacco shreds. J. Anal. Appl. Pyrolysis, 2005, 74, 181192.

(12) Becidan, M.; Várhegyi, G.; Hustad, J. E.; Skreiberg, Ø. Thermal decomposition of biomass wastes. A kinetic study. Ind. Eng. Chem. Res. 2007, 46, 2428 - 2437.

(13) Várhegyi, G.; Bobály, B.; Jakab, E.; Chen, H.: Thermogravimetric study of biomass pyrolysis kinetics. A distributed activation energy model with prediction tests. Energy Fuels, 2011, 25, 24-32. 
(14) Eaton, A. M.; Smoot, L. D.; Hill, S. C.; Eatough, C. N. Components, formulations, solutions, evaluation, and application of comprehensive combustion models. Progr. Energy Combust. Sci. 1999, $25,387-436$.

(15) Várhegyi, G.; Czégény, Zs.; Liu, C.; McAdam, K.: Thermogravimetric analysis of tobacco combustion assuming DAEM devolatilization and empirical char-burnoff kinetics. Ind. Eng. Chem. Res., 2010, 49, 1591-1599.

(16) Várhegyi, G. Aims and methods in non-isothermal reaction kinetics. J. Anal. Appl. Pyrolysis 2007, 79, 278-288.

(17) Várhegyi, G.; Mészáros, E.; Antal, M. J., Jr.; Bourke, J.; Jakab, E. Combustion kinetics of corncob charcoal and partially demineralized corncob charcoal in the kinetic regime. Ind. Eng. Chem. Res. 2006, 45, 4962-4970.

(18) Mészáros, E.; Várhegyi, G.; Jakab, E.; Marosvölgyi, B.: Thermogravimetric and reaction kinetic analysis of biomass samples from an energy plantation. Energy Fuels 2004, 18, 497-507.

(19) Várhegyi, G.; Till, F. Computer processing of thermogravimetric - mass spectrometric and high pressure thermogravimetric data. Part 1. Smoothing and differentiation. Thermochim. Acta 1999, 329, $141-145$.

(20) Várhegyi, G.; Chen, H.; Godoy, S. Thermal decomposition of wheat, oat, barley and Brassica carinata straws. A kinetic study. Energy Fuels 2009, 23, 646-652.

(21) Donskoi, E.; McElwain, D. L. S. Optimization of coal pyrolysis modeling. Combust. Flame 2000, 122, 359-367.

(22) Press, W. H.; Flannery, B. P.; Teukolsky, S. A.; Vetterling, W. T. Numerical Recipes. The Art of Scientific Computing. 2nd ed., Cambridge University Press, Cambridge (U.K.), 1992. (Online Internet edition: http://www.nrbook.com/a/bookfpdf.php .)

(23) Kolda, T. G.; Lewis, R. M.; Torczon, V. Optimization by direct search: New perspectives on some classical and modern methods. SIAM Rev. 2003, 45, 385-482.

(24) Capart, R.; Khezami, L.; Burnham, A. K.: Assessment of various kinetic models for the pyrolysis of a microgranular cellulose. Thermochim. Acta 2004, 417, 79-89.

(25) Várhegyi, G.; Szabó, P.; Jakab, E.; Till, F.; Richard J-R. Mathematical modeling of char reactivity in $\mathrm{Ar}-\mathrm{O}_{2}$ and $\mathrm{CO}_{2}-\mathrm{O}_{2}$ mixtures. Energy Fuels 1996, 10, 1208-1214.

(26) Várhegyi, G.; Antal, M. J., Jr.; Székely, T.; Szabó, P.: Kinetics of the thermal decomposition of cellulose, hemicellulose and sugar cane bagasse. Energy Fuels 1989, 3, 329-335. 
(27) Branca, C.; Di Blasi C. Parallel- and series-reaction mechanisms of wood and char combustion. Thermal Science 2004, 8, 51-63.

(28) Manyà, J. J.; Velo, E.; Puigjaner, L. Kinetics of Biomass Pyrolysis: a Reformulated ThreeParallel-Reactions Model. Ind. Eng. Chem. Res., 2003, 42, 434 -441.

(29) Conesa, J. A.; Domene, A. Biomasses pyrolysis and combustion kinetics through n-th order parallel reactions. Thermochim. Acta, 2011, 523, 176-181.

(30) Barneto, A. G.; Carmona, J. A.; Conesa Ferrer, J. A.; Díaz Blanco, M. J. Kinetic study on the thermal degradation of a biomass and its compost: Composting effect on hydrogen production. Fuel, 2010, $89,462-473$.

(31) House, J. Principles of Chemical Kinetics. 2nd edition, Academic Press 2007.

(32) Bhatia; S. K; Perlmutter, D. D. A random pore model for fluid-solid reactions: I. Isothermal kinetic control. AIChE J. 1980, 26, 379-386.

(33) Gavalas, G. R. A random capillary model with application to char gasification at chemically controlled rates. AIChE J. 1980, 26, 577-585. 